\title{
Three-dimensional modelling and morphometric investigation of computed tomography images of brown bear's (Ursus arctos) ossa cruris (Zeugopodium)
}

\author{
i. Demircioğlu1 ${ }^{1}$, G. Kirbaş Doğan², F. Aksünger Karaavci³, i. Gürbüz ${ }^{4}$, Y. Demiraslan ${ }^{4}$ \\ ${ }^{1}$ Department of Anatomy, Faculty of Veterinary Medicine, Harran University, Sanliurfa, Turkey \\ 2Department of Anatomy, Faculty of Veterinary Medicine, Kafkas University, Kars, Turkey \\ ${ }^{3}$ Department of Anatomy, Faculty of Veterinary Medicine, Bingol University, Bingöl, Turkey \\ ${ }^{4}$ Department of Anatomy, Faculty of Veterinary Medicine, Mehmet Akif Ersoy University, Burdur, Turkey
}

[Received: 10 August 2019; Accepted: 4 November 2019]

\begin{abstract}
Background: This study was aimed to examine the detailed morphometrical and morphological characteristics of the bone by creating three-dimensional images through multidetector computed tomography images of ossa cruris in brown bears. Materials and methods: Four brown bear ossa cruris were used in the study. Results: It was observed that tibia and fibula articulated at proximal and distal epiphysis and they combined, and ossa cruris were shaped in this way. Cochlea tibiae were determined to be sagittally oriented. The length of the tibia was determined to be $268.97 \mathrm{~mm}$ and $266.32 \mathrm{~mm}$ at right and left sides, respectively. The length of the fibula was determined to be $249.16 \mathrm{~mm}$ and $250.19 \mathrm{~mm}$ on average at the right and left sides, respectively. In consequence of the correlation analysis, statistical relationships at different rates were detected between the measured values.

Conclusions: Detailed anatomical examinations are very important in terms of determining the similarities and differences of bear bones with those of the other species in the order Carnivora. Therefore, it is thought that this study will reveal detailed characteristics of ossa cruris of bears and provide data for further studies on archaeological and forensic sciences. (Folia Morphol 2020; 79, 4: 811-816)
\end{abstract}

Key words: brown bear, ossa cruris, three-dimensional modelling, morphometry

\section{INTRODUCTION}

Brown bears (Ursus arctos) are one of the biggest carnivores commonly found in Turkey. They have large habitats dating back to 20 million years ago and ranging from seashores to steppes [13, 22]. The habitats of brown bears, which have a wide range in also our country, have been limited to Black Sea and Eastern Anatolian Regions today due to human impacts and destructions of forests [1,5]. Because of these reasons, Brown bear (Ursus arctos) has been listed among the species of the least concern in the red list that the International Union for Conservation of Nature and Natural Resources published in 2017 [14].

The skeletal system of brown bears is like the basic skeletal system of carnivores. But, as its body weight is greater when compared with the other 
carnivores, the bones that make up its skeletal system are shorter and more durable. Although many carnivores are digitigrade, bears are plantigrade. Being plantigrade helps them to stand on their two legs comfortably $[8,13]$. As the bears have existed throughout many periods of human history, the findings of bears are commonly found in archaeological excavations and they can be confused with human bones [10].

In mammals, ossa cruris consist of two bones, tibia and fibula. Tibia is a long bone that joins the structure of the knee joint in all mammals; the surface of tibial cochlea shows anatomical differences according to ankle's degree of stabilisation and ability to move [20]. While fibula is found shrunken in ruminants and equidae, its length is equal to that of the tibia in sus and carnivores [4].

Today, three-dimensional (3D) modelling technology is among the most frequently preferred methods in the fields of medicine and veterinary. Detailed examinations can be performed in tissues and organs that are viewed three-dimensionally using the medical imaging techniques that take cross-sectional images. Also, while these models provide a better understanding of complicated anatomical and pathological structures, they also provide benefit for forensic sciences and anthropological studies $[6,23]$.

There are various studies on the osteology of lynxes [19], dogs [9], martens [3], badgers [18], and Van cats [25], which are among the various species in the order Carnivora. However, no information on ossa cruris of today's brown bears could be reached in the literature reviews. Therefore, our study was planned to reveal the 3D model of brown bear's ossa cruris using multidetector computed tomography (MDCT) images and examine its macroanatomical and morphometric characteristics through these 3D modelling.

\section{MATERIALS AND METHODS}

Ossa cruris of four male brown bears (8 ossa cruris) were used in our study. General Directorate of Nature Conservation and National Parks, Ministry of Agriculture and Forestry of the Republic of Turkey (E.2242114/2018) granted the necessary permission for the study. The bone materials that were used in the study were scanned with 64-detector computed tomography (General Electronic Revolution) device with $80 \mathrm{kV}, 200 \mathrm{MA}, 639 \mathrm{mGY}$ and cross-sectional thickness of $0.625 \mathrm{~mm}$. In determining the dose and scanning protocol, Prokop [21] was taken as refer-

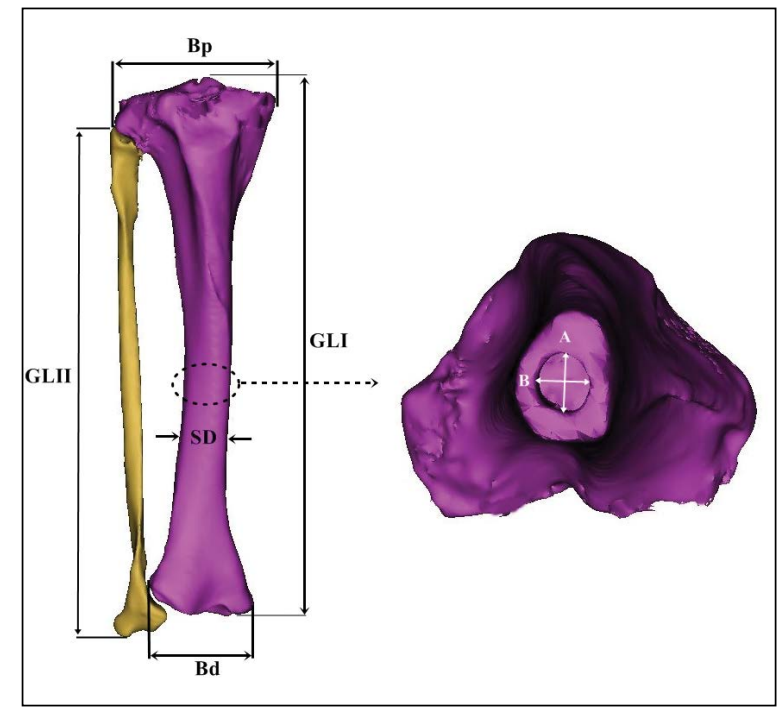

Figure 1. Reference measurement points of ossa cruris; A craniocaudal diameter of cavum medullare; $\mathrm{B}$ - lateromedial diameter of cavum medullare; GLI — length of tibia; GLII — length of fibula; SD — the smallest width of tibia diaphysis; $\mathrm{Bd}$ - distal width of tibia; $\mathrm{Bp}$ - proximal width of tibia.

ence. After the scanned images were saved in DICOM format, they were transferred into the MIMICS 20.1 (The Materialise Group, Leuven, Belgium) programme to create a 3D model and the relevant measurements and examinations on the bone were carried out. Osteometrical measurements were taken on the created 3D images (Fig. 1). Von Den Driecsh [7] was taken as reference in determining these measurement points.

The measurement points that were taken on the models obtained from the computed tomography images of ossa cruris: GL1 — length of tibia; GL2 - length of fibula; Bp - proximal width of tibia; Bd - distal width of tibia; Sd - the smallest width of tibia diaphysis; TMD ( $\mathrm{Cr}-\mathrm{c})$ - craniocaudal diameter of tibia's cavum medullare; TMD (LM) — lateromedial diameter of tibia's cavum medullare; TV — tibia volume; TSA - tibia surface area; FV — fibula volume; FSA - fibula surface area.

\section{Statistical analysis}

SPSS (22.0 version) software package was used for the statistical analyses in the study. Mean values and standard deviations of the measured parameters, and correlation coefficients between these parameters were detected and statistical evaluations were made. Shapiro-Wilk test was used to determine the normality of the data. The relationship between the measurement parameters was determined with the Pearson correlation $(r)$ test. 


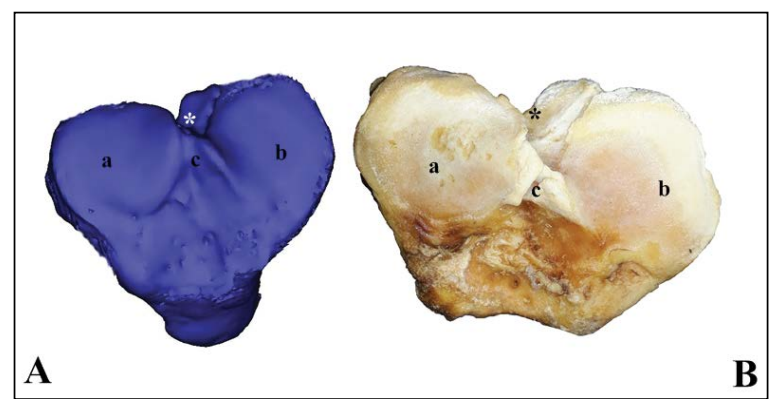

Figure 2. View of tibia from proximal; $\mathbf{A}$. Three-dimensional view; B. Macroanatomical view; $a$ - condylus lateralis; $b$ - condylus medialis; c - eminentia intercondylaris; ${ }^{*}$ incisura poplitei.

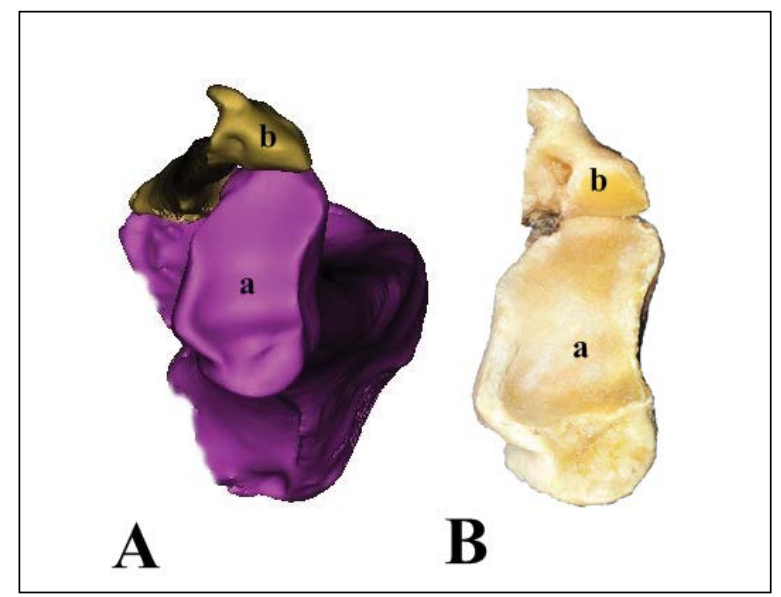

Figure 3. View of ossa cruris from distal; A. Three dimensional view; B. Macroanatomical view; $a-$ cochlea tibiae; $b-$ distal of fibula.

Canon EOS-700D camera was used in taking macro photographs. The study was based on Nomina Anatomica Veterinaria (2017) [24].

\section{FINDINGS AND RESULTS}

It was observed that in brown bears ossa cruris were fully developed and made up of tibia and fibula that articulated at proximal and distal with each other. Condyles, which are found in the epiphysis proximalis of tibia, were found to separate from each other via incisura poplitei in the caudal aspect. Eminentia intercondylaris, a nonarticular area between condylus lateralis and condylus medialis, were observed to exist (Fig. 2). It was detected that this area was divided into two as tuberculum intercondylare mediale and tuberculum intercondylare laterale, and tuberculum intercondylare mediale was slightly higher than tuberculum intercondylare laterale.

It was observed that cochlea tibiae, which is located in the distal part of the tibia, had two straight articular

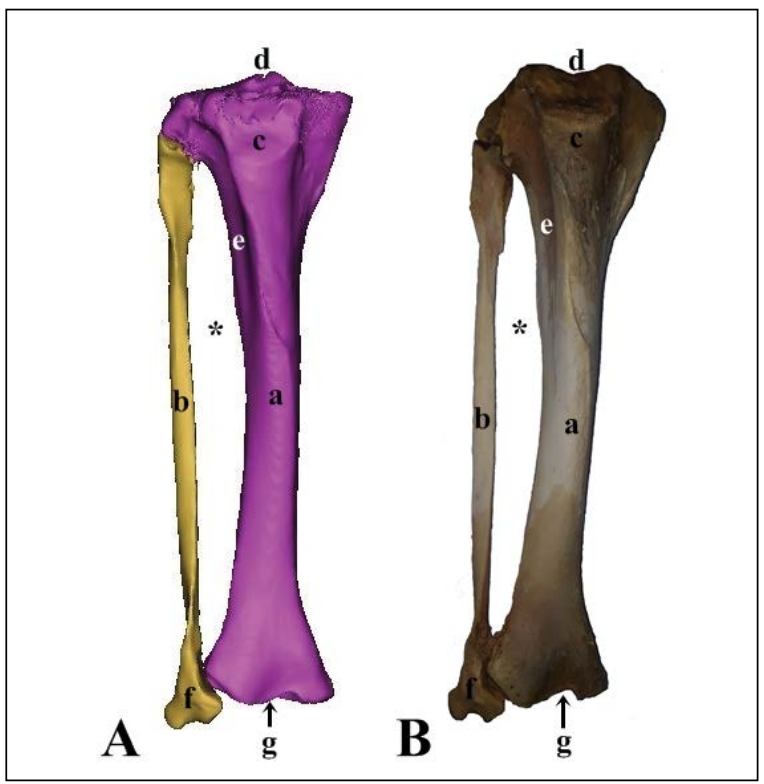

Figure 4. View of ossa cruris from cranial; $\mathbf{A}$. Three-dimensional view; B. Macroanatomical view; a - tibia; b - fibula; $c$ tuberositas tibia; $\mathrm{d}$ - eminentia intercondylaris; $\mathrm{e}$ - sulcus extensorius; $\mathrm{f}$ - distal of the fibula; $\mathrm{g}-$ cochlea tibiae; ${ }^{*}$ spatium interosseum.

pits. Malleolus medialis was found to exist in the medial of the tibia and a distinct sulcus malleolaris was detected on it (Fig. 3). The fibula was found to extend to distal, retaining its bone-shaped thickness and end by shaping malleolus lateralis. Also, the distal part of the fibula was determined to exceed tibia. It was observed that spatium interosseum, found between tibia and fibula, was fixed along the lengths of the bones (Fig. 4).

The morphometric values found in the study were presented in Table 1. Based on this, the length of the tibia was determined to be $268.97 \mathrm{~mm}$ and $266.32 \mathrm{~mm}$ in the right and left side, respectively. The length of the fibula was measured to be $249.16 \mathrm{~mm}$ and $250.19 \mathrm{~mm}$ in the right and left side, respectively. When all the determined morphometric parameters were compared in terms of direction (right-left), no statistical difference was found ( $p>0.05$ ).

The correlation values of the morphometric data obtained in the study were presented in Table 2. In consequence of the correlation analysis, it was found that the GL1 value showed a highly positive correlation ( $p<0.05$ ) with the Bp, SD, Bd, GL2, TV, TYA, FV values, but it showed a weak negative correlation with the TME $(\mathrm{Cr}-\mathrm{C})$ value $(\mathrm{p}>0.05)$.

\section{DISCUSSION}

Many different conservation measures are implemented so that brown bears, which have a very 
Table I. Analyses of mean values and standard deviations of the osteometric measurements

\begin{tabular}{|c|c|c|c|c|}
\hline & Direction & Mean value & Standard deviation & P-value \\
\hline \multirow[t]{2}{*}{$\mathrm{GL} 1$ [mm] } & Right & 268.97 & 25.62 & $>0.05$ \\
\hline & Left & 266.32 & 24.92 & $>0.05$ \\
\hline \multirow[t]{2}{*}{$\mathrm{Bp}[\mathrm{mm}]$} & Right & 75.32 & 4.66 & $>0.05$ \\
\hline & Left & 75.17 & 5.94 & $>0.05$ \\
\hline \multirow[t]{2}{*}{$\mathrm{SD}[\mathrm{mm}]$} & Right & 23.89 & 1.64 & $>0.05$ \\
\hline & Left & 24.41 & 1.08 & $>0.05$ \\
\hline \multirow[t]{2}{*}{$\mathrm{Bd}[\mathrm{mm}]$} & Right & 59.48 & 5.86 & $>0.05$ \\
\hline & Left & 58.75 & 3.82 & $>0.05$ \\
\hline \multirow[t]{2}{*}{$\mathrm{GL} 2[\mathrm{~mm}]$} & Right & 249.16 & 27 & $>0.05$ \\
\hline & Left & 250.19 & 24.28 & $>0.05$ \\
\hline \multirow[t]{2}{*}{$\mathrm{TMD}[\mathrm{Cr}-\mathrm{c}][\mathrm{mm}]$} & Right & 11.5 & 0.12 & $>0.05$ \\
\hline & Left & 11.6 & 0.08 & $>0.05$ \\
\hline \multirow[t]{2}{*}{ TMD [LM] [mm] } & Right & 11.3 & 0.08 & $>0.05$ \\
\hline & Left & 11.3 & 0.01 & $>0.05$ \\
\hline \multirow[t]{2}{*}{ TV $\left[\mathrm{mm}^{3}\right]$} & Right & 151062.79 & 57225.78 & $>0.05$ \\
\hline & Left & 150286.72 & 50416.1 & $>0.05$ \\
\hline \multirow[t]{2}{*}{ TSA [mm²] } & Right & 79879.21 & 9230.88 & $>0.05$ \\
\hline & Left & 83670.6 & 23798.94 & $>0.05$ \\
\hline \multirow[t]{2}{*}{$\mathrm{FV}\left[\mathrm{mm}^{3}\right]$} & Right & 19676.2 & 2426.2 & $>0.05$ \\
\hline & Left & 19197.31 & 3719.88 & $>0.05$ \\
\hline \multirow[t]{2}{*}{$\mathrm{FSA}\left[\mathrm{mm}^{2}\right]$} & Right & 14242.95 & 1302.94 & $>0.05$ \\
\hline & Left & 13757.08 & 2694.82 & $>0.05$ \\
\hline
\end{tabular}

Abbreviations - see text

Table 2. Correlation analyses of the osteometric measurements [mm]

\begin{tabular}{|c|c|c|c|c|c|c|c|c|c|c|c|}
\hline & GL1 & $\mathrm{Bp}$ & SD & Bd & GL2 & $\begin{array}{l}\text { TMD } \\
\text { (Cr-C) }\end{array}$ & $\begin{array}{l}\text { TMD } \\
\text { (LM) }\end{array}$ & TV & TSA & $\mathrm{FV}$ & FSA \\
\hline GL1 & - & $0.879 * *$ & $0.716^{*}$ & $0.950^{* * *}$ & $0.836^{* *}$ & -0.103 & 0.201 & $0.944^{* * *}$ & $0.917^{* *}$ & $0.874^{* *}$ & 0.601 \\
\hline Bp & & - & $0.827^{*}$ & $0.826^{*}$ & $0.771^{*}$ & -0.059 & -0.050 & $0.972^{* * *}$ & $0.977^{* * *}$ & $0.801^{*}$ & 0.403 \\
\hline SD & & & - & 0.584 & 0.438 & -0.457 & -0.359 & $0.843^{* *}$ & $0.851^{* *}$ & 0.516 & -0.003 \\
\hline $\mathrm{Bd}$ & & & & - & $0.884^{* *}$ & 0.084 & 0.338 & $0.898^{* *}$ & $0.850^{* *}$ & $0.791^{*}$ & 0.593 \\
\hline GL2 & & & & & - & 0.451 & 0.588 & $0.819^{*}$ & $0.751^{*}$ & $0.878^{* *}$ & $0.801^{*}$ \\
\hline $\mathrm{TMD}$ (Cr-C) & & & & & & - & $0.764^{*}$ & -0.077 & -0.152 & 0.183 & 0.520 \\
\hline TMD (LM) & & & & & & & - & 0.047 & -0.053 & 0.343 & $0.751^{*}$ \\
\hline TV & & & & & & & & - & $0.969 * * *$ & $0.830^{*}$ & 0.447 \\
\hline TSA & & & & & & & & & - & $0.797^{*}$ & 0.400 \\
\hline FV & & & & & & & & & & - & $0.825^{*}$ \\
\hline FSA & & & & & & & & & & & - \\
\hline
\end{tabular}

${ }^{*} p<0.05 ;{ }^{* *} p<0.01 ;{ }^{* *} p<0.001 ;$ abbreviations - see text

common habitat on earth, sustain their potentials. Despite these measures, reductions are observed in the populations of brown bears due to poaching or conservation [2]. When considered along with the other species that are extinct or endangered, it is important to increase the brown bear population or preserve the number in terms of the presence of the species and the other species affected. In this sense, 
bone materials of 4 male brown bear were used in the study to record the morphological and osteometric data of ossa cruris of brown bear, one of the wild animals that exist today, to transfer them to the future. The limitations of the study have been the number of bone materials belonging to this animal, which is forbidden to hunt and kill. Therefore, it was not possible to compare female and male samples and reveal the osteometric means in more samples.

Tibia and fibula, which make up the ossa cruris of brown bears, were observed to articulate and combine at proximal and distal. Özgel and Aykut [19], Atalar and Özdemir [3], Özdemir and Karan [18], reported similar findings in their studies on lynx (Lynx lynx), martens (Martens foina), and badger (Meles meles), respectively. However, Yilmaz et al. [26] reported that these two bones knitted at proximal and articulated at distal in Indian porcupines (Hystrix cristata). Dyce et al. [8] reported that spatium interosseum extended to distal along the entire course of the bone in sus, and this aperture was limited to the proximal part in canis. In this study, spatium interosseum was found to extend from proximal to distal.

It was observed that tuberculum intercondylare mediale, found in the epiphysis proximalis of tibia, was higher than tuberculum intercondylare laterale with a slight difference. The obtained finding was found to be in parallels with the other domestic mammals [12] except for sus [12] and wild boars [11]. While cochlea tibiae was reported to be sagittally oriented in humans [10], Indian porcupines (Hystrix cristata) [26], wild boars (Sus scrofa) [11], squirrels (Sciurus vulgaris) [17], it was reported to be obliquely oriented in lynxes (Lynx lynx) [19] and dogs [9]. In the study, cochlea tibiae of brown bears were observed to be sagittally oriented.

In their studies on humans and American black bears, Orcholl et al. [16] reported the length, mediolateral diameter, and anteroposterior diameter of the tibia to be $359.6 \mathrm{~mm}$ and $230 \mathrm{~mm}, 20.4 \mathrm{~mm}$ and $20.1 \mathrm{~mm}$, and $29.9 \mathrm{~mm}$ and $26.7 \mathrm{~mm}$, respectively. The length of the fibula was determined to be 359.8 in humans and $209.9 \mathrm{~mm}$ in American black bears. In the measurements of canine tibiae that were excavated in the Van-Yoncatepe excavations, Onar and Belli [15] reported the length of tibia to be $181.3 \mathrm{~mm}$ at the right side, $179.2 \mathrm{~mm}$ at the left side, and the middle diaphysis diameter to be $12.2 \mathrm{~mm}$ at the right and $12.4 \mathrm{~mm}$ at the left. In our study, the length of the tibia, craniocaudal and lateromedial diameters were found to be $268.97 \pm 12.81 \mathrm{~mm}, 11.5 \pm 0.06 \mathrm{~mm}$, and $11.3 \pm 0.04 \mathrm{~mm}$ at the right side, and $266.32 \pm$ $\pm 12.46 \mathrm{~mm}, 11.6 \pm 0.014 \mathrm{~mm}$, and $11.3 \pm 0.05 \mathrm{~mm}$ at the left side, respectively. Based on this, it is seen that the brown bear tibia is longer when compared with American black bear [16] and canine [15] tibia, and shorter than human tibia [16].

\section{CONCLUSIONS}

The literature was reviewed and no study in which MDCT technique was used in the macroanatomical and morphometric analysis of brown bear's (Ursus arctos) ossa cruris was reached. With this study, parameters of ossa cruris of the brown bear were obtained and it is thought that these values may be a reference to studies in the field of osteoarchaeological and forensic sciences in the taxonomical classification of species because of their similarities with human osteology. Also, we are of the opinion that the basic anatomical data on brown bears will be enriched with this study.

\section{REFERENCES}

1. Ambarlı $\mathrm{H}$, Bilgin C. Human-Brown bear conflicts in artvin, northeastern Turkey: encounters, damage, and attitudes. Ursus. 2008; 19(2): 146-153, doi: 10.2192/1537-617619.2.146.

2. Anonymous. http://www.defenders.org/sites/default/ files/publications/a_place_for_grizzlies.pdf (Insert Date; 09.08.2019)

3. Atalar Ö, Özdemir D. Macro-anatomical investigatios on the skeletons of marten (Martes fonia). II. Ossa Membri Pelvini. Fırat Üniversitesi Sağlık Bilimleri Veteriner Dergisi. 2002; 16: 233-236.

4. Bahadır A, Yıldız H. Veteriner Anatomi: Hareket Sistemi \& iç Organlar. Ezgi Kitabevi, Bursa 2008.

5. Can Ö, Togan i. Status and management of brown bears in Turkey. Ursus. 2004; 15(1): 48-53, doi: 10.2192/1537-6176(2004)015<0048:samobb>2.0.co;2.

6. D'Urso PS, Barker TM, Earwaker WJ, et al. Stereolithographic biomodelling in cranio-maxillofacial surgery: a prospective trial. J Craniomaxillofac Surg. 1999; 27(1): 30-37, doi: 10.1016/s1010-5182(99)80007-9, indexed in Pubmed: 10188125.

7. Driesch VDA. Guide to the measurement of animal bones from archaeological sites. Peabody Museum Bulletin I. Cambridge M.A. Harvard University. 1976: 60-62.

8. Dyce KM, Sack WO, Wensing CJG. Textbook of Veterinary Anatomy.Third Edition. Saunders, Philadelphia, United States 2002.

9. Evans HE, De Lahunta A. Miller's anatomy of the dogE-Book. Elsevier Health Sciences, 2013.

10. France DL. Human and nonhuman bone identification: a color atlas. CRC, Press 2008.

11. Karan M. Yaban domuzlarında (Sus scrofa) arka bacak kemiklerinin makro-anatomik olarak incelenmesi. Fırat 
Üniversitesi Sağlık Bilimleri Veteriner Dergisi. 2012; 26: 31-34.

12. König HE, Liebich HG. (Eds.). Veterinary anatomy of domestic mammals: textbook and colour atlas. Schattauer, Verlag 2013.

13. Marshall Cavendish Corporation. Mammal anatomy: An illustrated guide. Marshall Cavendish. New York 2010.

14. McLellan BN, Proctor MF, Huber D, et al. Ursus arctos. The IUCN Red List of Threatened Species 2017. e.T41688A121229971, doi: 10.2305/iucn.uk.2017-3.rlts. t41688a121229971.en.

15. Onar V, Belli O. Estimation of shoulder height from long bone measurements on dogs unearthed from the Van-Yoncatepe early Iron Age necropolis in Eastern Anatolia. Revue de médecine vétérinaire. 2005; 156(1): 53-60.

16. Orcholl JL, Scholar M, Hudson J. Diagnostic Criteria for the Comparison of Human and American Black Bear Skeletal Elements. Electronic document. http://www.uwm.edu/Dept/ Grad_Sch/McNair/2001/jackieorcholl.htm (accessed 2006).

17. Özdemir D, Atalar Ö. Macro-anatomical investigations of the skeletons of squirrel (Sciurus vulgaris). II. Ossa membri pelvini. Fırat Üniversitesi Sağlık Bilimleri Veteriner Dergisi. 2003; 17: 151-154.

18. Özdemir D, Karan M. Porsuk (Meles meles) iskelet sistemi üzerinde makro- anatomik araştırmalar II. Ossa membri pelvini. Fırat Üniversitesi Sağlık Bilimleri Veteriner Dergisi. 2001; 15(2): 397-400.
19. Özgel Ö, Aykut M. Macroanatomical Investigation on the Ossa Membri Pelvini of Anatolian Bobcat, Lynx lynx. Pakistan J Zool. 2015; 47(5): 1492-1494.

20. Polly PD. Limbs in mammalian evolution. Fins into limbs: evolution, development and transformation. 2007: 245-268.

21. Prokop M. General principles of MDCT. Eur J Radiol. 2003; 45 Suppl 1: S4-10, doi: 10.1016/s0720-048x(02)00358-3, indexed in Pubmed: 12598021.

22. Turan N. Game and Wild Animals of Turkey-Mammals. Ankara (Turkey). (In Turkish): 1984.

23. Verhoff MA, Ramsthaler F, Krähahn J, et al. Digital forensic osteology--possibilities in cooperation with the Virtopsy project. Forensic Sci Int. 2008; 174(2-3): 152-156, doi: 10.1016/j.forsciint.2007.03.017, indexed in Pubmed: 17451898

24. Veterinaria NA. Revised 6 th edn. International Committee on Veterinary Gross Anatomical Nomenclature. (ICVGAN): 2017.

25. Yılmaz O. Van kedilerinde ön bacak iskeletinin bilgisayarlı tomografi ile üç boyutlu olarak incelenmesi. Van Yüzüncü Yıl Üniversitesi Sağlık Bilimleri Enstitüsü, Doktora Tezi Van. 2018.

26. Yılmaz S, Özkan Z, Özdemir D. Oklu Kirpi (Hystrix cristata) iskelet sistemi üzerinde makro-anatomik araştırmalar. I. Ossa membri thoracici. Tr J Vet Anim Sci. 1998; 22: 389-392. 